\title{
$\mathrm{B}$ 과 $\mathrm{Cu}$ 가 포함된 고강도 저합금강의 연속냉각 변태와 미세조직 및 기계적 특성
}

\author{
황병철 ${ }^{\dagger}$ \\ 서울과학기술대학교 신소재공학과
}

\section{Continuous Cooling Transformation, Microstructure and Mechanical Properties of High-Strength Low-Alloy Steels Containing B and $\mathrm{Cu}$}

\author{
Byoungchul Hwang ${ }^{\dagger}$
}

\author{
Department of Materials Science and Engineering, \\ Seoul National University of Science and Technology, Seoul 139-743, Korea
}

(2013년 8월 27일 접수 : 2013년 8월 27일 최종수정 : 2013년 9월 9일 채택)

\begin{abstract}
This study investigated the continuous cooling transformation, microstructure, and mechanical properties of highstrength low-alloy steels containing B and $\mathrm{Cu}$. Continuous cooling transformation diagrams under non-deformed and deformed conditions were constructed by means of dilatometry, metallographic methods, and hardness data. Based on the continuous cooling transformation behaviors, six kinds of steel specimens with different $\mathrm{B}$ and $\mathrm{Cu}$ contents were fabricated by a thermomechanical control process comprising controlled rolling and accelerated cooling. Then, tensile and Charpy impact tests were conducted to examine the correlation of the microstructure with mechanical properties. Deformation in the austenite region promoted the formation of quasi-polygonal ferrite and granular bainite with a significant increase in transformation start temperatures. The mechanical test results indicate that the B-added steel specimens had higher strength and lower upper-shelf energy than the B-free steel specimens without deterioration in low-temperature toughness because their microstructures were mostly composed of lower bainite and lath martensite with a small amount of degenerate upper bainite. On the other hand, the increase of $\mathrm{Cu}$ content from $0.5 \mathrm{wt} . \%$ to $1.5 \mathrm{wt} . \%$ noticeably increased yield and tensile strengths by $100 \mathrm{MPa}$ without loss of ductility, which may be attributed to the enhanced solid solution hardening and precipitation hardening resulting from veryfine $\mathrm{Cu}$ precipitates formed during accelerated cooling.
\end{abstract}

Key words high-strength low-alloy(HSLA) steel, thermo-mechanical control process(TMCP), continuous cooling transformation, mechanical properties, $\mathrm{B}, \mathrm{Cu}$.

\section{1. 서 론}

구조용 철강 재료의 경우 강도와 인성을 동시에 확보 하려는 노력은 다양한 합금설계와 열처리 방법을 통해 꾸준히 진행되어 왔다. ${ }^{1-3)}$ 최근 자원 재활용, 지구 온난 화와 같은 환경적인 문제와 함께 원자재비 상승, 고유 가에 따른 경제적인 측면이 크게 부각되면서 친환경 저 가 원소의 활용 $(\mathrm{C}, \mathrm{N}, \mathrm{B}, \mathrm{Cu}$ 등)과 제조 공정의 단축을 통해 보다 환경 친화적이고 경제적인 방법으로 고강도 저합금강(high-strength low-alloy steel, HSLA)을 제조하
려는 연구가 큰 관심을 받고 있다. 그 대표적인 예가 제 어 압연과 가속 냉각을 이용한 가공 열처리(thermomechanical control process, TMCP) 제조 기술이다.,5) 일반적으로 $\mathrm{Ni}, \mathrm{Cr}, \mathrm{Mo}$ 등 고가의 합금원소를 많이 첨 가할 경우 고강도와 저온인성을 동시에 만족시킬 수 있 지만, 원소재의 가격이 증가하기 때문에 경제적인 측면 에서 바람직하지 않다. 따라서 저가의 합금원소를 활용 하면서 제어 압연과 가속 냉각에 의해 베이나이트나 마 르텐사이트와 같은 저온 변태 조직(low-temperature transformation products)을 형성시켜 고강도와 저온인성을 동

\footnotetext{
${ }^{\dagger}$ Corresponding author

E-Mail : bhwang@seoultech.ac.kr (B. Hwang, Seoul Nat'l Univ. of Sci. and Tech.)
}

(C) Materials Research Society of Korea, All rights reserved.

This is an Open-Access article distributed under the terms of the Creative Commons Attribution Non-Commercial License (http://creativecommons.org/licenses/by-nc/3.0) which permits unrestricted non-commercial use, distribution, and reproduction in any medium, provided the original work is properly cited. 
시에 얻기 위한 연구가 활발하게 진행되고 있다.

보론(B)은 $\mathrm{Mo}, \mathrm{Cr}$ 등의 다른 경화능 원소와 달리 수 십 $\mathrm{ppm}$ 의 미량 첨가를 통해서 강의 경화능을 효과적으 로 향상시켜 베이나이트 또는 마르텐사이트 변태를 촉진 시키는 매우 유용한 원소이다. ${ }^{4-6)}$ 구리 $(\mathrm{Cu})$ 는 $\mathrm{Ni}, \mathrm{Mn}$ 등 일반 오스테나이트 안정화 원소보다 친환경적이면서도 가 격적 측면에서 경쟁력이 있을 뿐만 아니라 페라이트 내 고용 한도가 낮음에도 불구하고 매우 뚜렷한 고용강화 및 경화능 효과와 함께 베이나이트 변태 영역에서 기지 조 직 내에 수 $\mathrm{nm}$ 크기의 입자를 석출시켜 부가적인 강화 효과를 얻을 수 있는 장점이 있다. ${ }^{47}$

본 연구에서는 친환경 저가원소인 $\mathrm{B}$ 과 $\mathrm{Cu}$ 를 적극 활 용하여 기계적 특성이 우수한 고강도 저합금강을 제어 압 연과 가속 냉각을 통해 제조하고자 하였다. 이를 위하여 먼저 오스테나이트에서의 변형과 다양한 냉각 속도에 따 른 연속냉각 변태(continuous cooling transformation) 거 동을 분석하고, 미세조직을 체계적으로 분석하였다. 이를 바탕으로 제어 압연을 통해 오스테나이트계 결정립을 미 세화 시킨 후 가속 냉각을 통해 다양한 미세조직을 갖 는 고강도 저합금강을 제조하고, 인장 및 충격 시험을 실시하여 미세조직과 기계적 특성의 상관관계를 규명하 였다.

\section{2. 실험 방법}

본 연구에서 사용된 재료는 $\mathrm{Fe}-0.07 \mathrm{C}-0.25 \mathrm{Si}-1.8 \mathrm{Mn}-0.7$ $(\mathrm{Ni}+\mathrm{Cr}+\mathrm{Mo})-0.01(\mathrm{Nb}+\mathrm{V}+\mathrm{Ti})-0.03 \mathrm{Al}(\mathrm{wt} . \%)$ 을 기본 조성 으로 하여 $\mathrm{B}$ 및 $\mathrm{Cu}$ 의 함량을 달리한 6 종류의 시편들 이다. 이제부터 편의상 이들 시편들을 ' $0 \mathrm{Cu}$ ', ' $0.5 \mathrm{Cu}$ ', ' $1.5 \mathrm{Cu}$ ', '0Cu-B', '0.5Cu-B', $1.5 \mathrm{Cu}-\mathrm{B}$ '로 표기하기로 한 다. 위의 표기에서 앞의 숫자는 $\mathrm{Cu}$ 함량(wt. \%)을, 뒤 의 문자는 $\mathrm{B}$ 첨가(약 $10 \mathrm{ppm})$ 를 나타낸다. 먼저 $0.5 \mathrm{Cu}$ 시편과 $0.5 \mathrm{Cu}-\mathrm{B}$ 시편에 대하여 오스테나이트 변형에 따 른 미변형(non-deformed) 및 변형(deformed) 연속냉각 변태 곡선을 작성하였다. 이를 위하여 열간 압연 모사 시 험기(model: Gleeble 3500, Dynamic Systems Inc.)를 이 용하여 $1,150{ }^{\circ} \mathrm{C}$ 에서 10 분간 유지 후 오스테나이트에서 의 변형 $\left(8500^{\circ} \mathrm{C}\right.$ 에서 $1 \mathrm{~s}^{-1}$ 의 변형률 속도로 $30 \%$ 변형 $)$ 유 무와 다양한 냉각 속도 $\left(0.2 \sim 50{ }^{\circ} \mathrm{C} / \mathrm{s}, 820^{\circ} \mathrm{C}\right.$ 에서 냉각 시 작)에서 얻어진 선팽창 곡선으로부터 변태 시작과 종료 온도를 측정하였고, 시편의 미세조직과 경도 변화를 관 찰하였다. 경도는 비스커 경도 시험기(model: FM-300, Future-Tech Corp.)를 이용하여 $300 \mathrm{~g}$ 의 하중 하에서 측 정하였다.

연속냉각 변태 거동에 대한 분석을 토대로 다양한 저 온 변태 조직을 형성시키기 위해 제어 압연 및 가속 냉
각 조건을 다음과 같이 설정하였다. 우선 $100 \mathrm{~mm}$ 두께 의 강재를 $1,150^{\circ} \mathrm{C}$ 에서 2 시간 정도 재가열한 후 $980^{\circ} \mathrm{C}$ 에서 압연을 시작하며, 재결정 온도 이상과 그 이하에서 각각 $50 \%$ 이상의 압하를 가하고, 오스테나이트 단상 영 역에서 마무리 압연을 실시하여 $15 \mathrm{~mm}$ 두께의 판재로 제 조하였다. 마무리 압연 후 $800{ }^{\circ} \mathrm{C}$ 에서 약 $250{ }^{\circ} \mathrm{C}$ 의 냉각 종료 온도까지 $20^{\circ} \mathrm{C} / \mathrm{s}$ 이상의 속도로 가속냉각하였다.

미세조직 분석은 판재의 윗면, 즉 L-T(longitudinal-transverse) 면을 관찰하였으며, 광학 현미경(model: EPIPHOT 200, Nikon)과 영상 분석기(SigmaScan Pro 4.0, Jandel Corp.)를 이용하여 각 상의 분율을 정량적으로 측정하였 다. 또한 저온 변태 조직의 하부 구조(substructure)를 분 석하기 위해 투과 전자현미경(transmission electron microscopy, TEM, model: JEM-2100F, JEOL)을 이용하여 다 양한 형태의 베이나이트와 마르텐사이트 조직을 관찰하 였다.

기계적 특성을 평가하기 위하여 판재 두께의 $1 / 2$ 되는 위 치에서 인장 및 충격 시편을 채취하였다. 인장 시험은 ASTM E8 시험법에 따라 sub-size 봉상 시편(표점거리 $25.4 \mathrm{~mm}$, 직경 $6.3 \mathrm{~mm})$ 으로 가공하고, 10 톤 용량의 만능 시험기(model: Instron 5882, Instron Co.)를 이용하여 $5 \mathrm{~mm} / \mathrm{min}$ 의 속도로 상온에서 실시하였다. 충격 시험은 ASTM E23 표준 시험법에 따라 T-L 방향으로 $10 \times 10$ $\times 55 \mathrm{~mm}$ 의 Charpy V-notch $(\mathrm{CVN})$ 시편으로 가공한 후 $500 \mathrm{~J}$ 용량의 충격 시험기(model: FAHC-J-500-01, JT Toshi Inc.)를 이용하여 $-196 \sim+100{ }^{\circ} \mathrm{C}$ 의 온도 범위에서 실시하였다. 저온인성을 평가하기 위한 연성-취성 천이 온 도(ductile-brittle transition temperature, DBTT)는 연성 과 취성 파면이 각각 $50 \%$ 인 온도로 결정하였다.

\section{3. 결과 및 고찰}

\section{1 연속냉각 변태}

오스테나이트에서의 변형에 따른 $0.5 \mathrm{Cu}$ 와 $0.5 \mathrm{Cu}-\mathrm{B}$ 시 편의 연속냉각 변태 곡선을 Fig. 1에, 이로부터 형성된 미세조직의 변화를 Fig. 2에 나타내었다. 미변형 및 변 형 연속냉각 변태 곡선에서 모두 냉각 속도가 빨라짐에 따라 변태 시작과 종료 온도는 모두 낮아지며, 미세조직 은 변태 온도에 따라 QPF(qausi-polygonal ferrite), GB (granular bainite), DUB(degenerate upper bainite), LB (lower bainite), LM(lath martensite)의 순서로 다양한 저온변태 조직이 형성되었다. ${ }^{1,2,8,9)} 0.5 \mathrm{Cu}-\mathrm{B}$ 시편은 $\mathrm{B}$ 첨 가에 의한 경화능 향상으로 인해 $0.5 \mathrm{Cu}$ 시편에 비해 변 태 시작과 종료 온도가 모두 낮아져 미세조직이 냉각 속 도에 따라 큰 차이를 나타낸다. 이들 미세조직을 살펴 보 면(Fig. 2), $0.5 \mathrm{Cu}$ 시편은 $50{ }^{\circ} \mathrm{C} / \mathrm{s}$ 의 냉각 속도에서 LB/ 

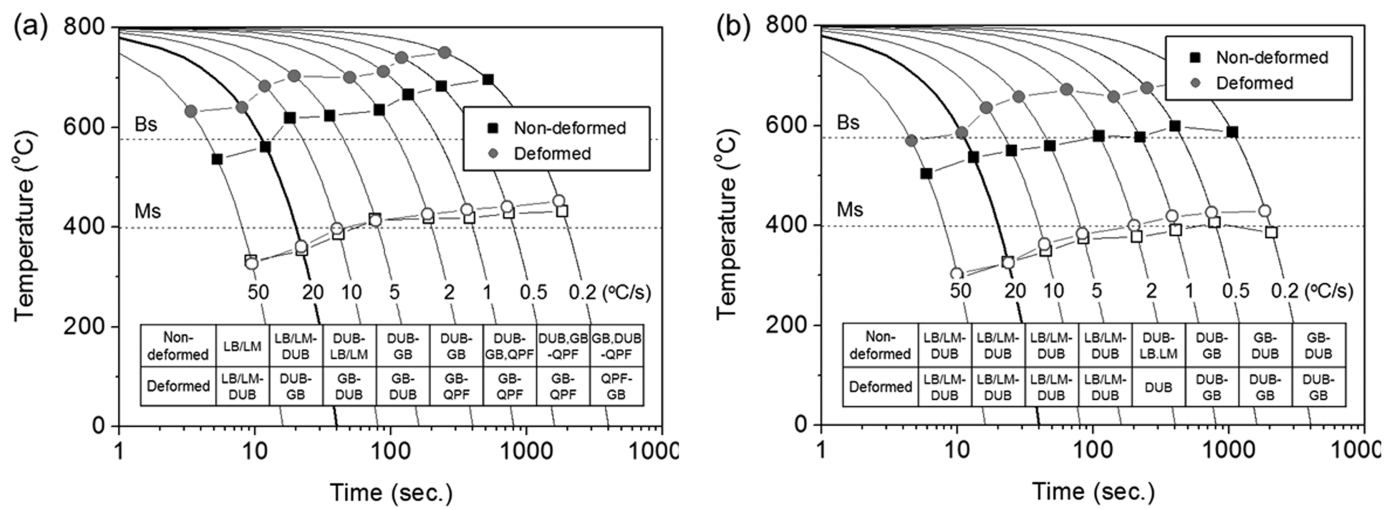

Fig. 1. Non-deformed and deformed continuous cooling transformation diagrams for the (a) $0.5 \mathrm{Cu}$ and (b) $0.5 \mathrm{Cu}-\mathrm{B}$ steel specimens. Solid and dotted symbols indicate transformation start and finish temperatures, respectively. Microstructure designation: QPF(quasi-polygonal ferrite), GB(granular bainite), DUB(degenerate upper bainite), LB(lower bainite), LM(lath martensite).

(a)

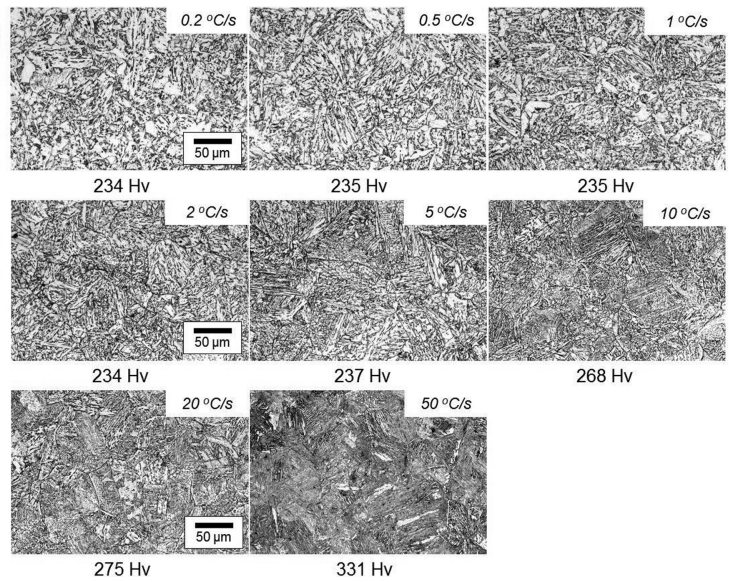

(b)

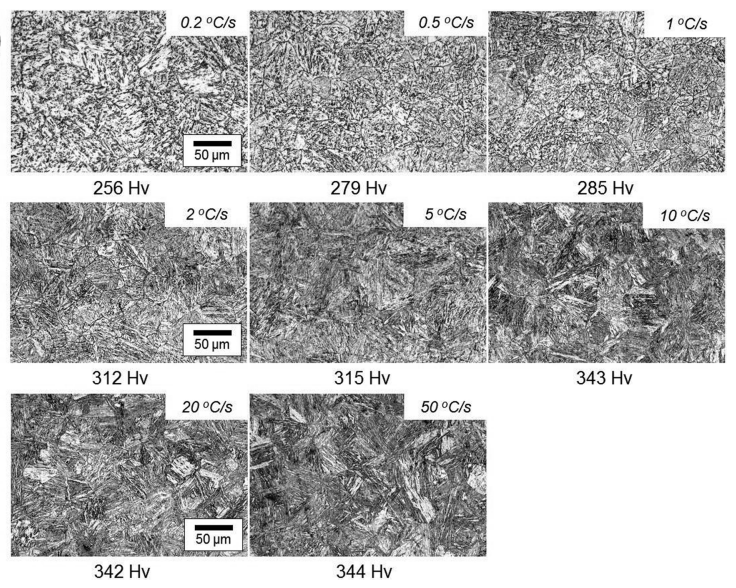

Fig. 2. Optical micrographs of the (a) $0.5 \mathrm{Cu}$ and (b) $0.5 \mathrm{Cu}$-B steel specimens obtained from non-deformed continuous cooling transformation. Nital etched.

$\mathrm{LM}$ 조직이 나타나는 반면, $0.5 \mathrm{Cu}-\mathrm{B}$ 시편은 $10{ }^{\circ} \mathrm{C} / \mathrm{s}$ 의 냉각 속도에서부터 $\mathrm{LB} / \mathrm{LM}$ 조직이 나타났다.

일반적으로 오스테나이트 영역에서의 변형은 오스테나 이트 결정립의 내부 에너지를 증가시키고, 내부에 전위 나 변형띠와 같은 결함들을 형성시켜 오스테나이트에서 페라이트로의 변태를 촉진시킨다. ${ }^{4,5)}$ 따라서 $\mathrm{B}$ 첨가에 관 계없이 이러한 오스테나이트 변형은 변태 시작 온도를 크게 상승시키며, 변태 종료 온도에는 큰 영향을 주지 않는다. 그러나 B 첨가 유무에 따라 미변형 및 변형 연 속냉각 변태 곡선의 변태 시작 온도는 냉각 속도에 따 라 조금 다른 양상을 나타낸다. 즉, $10{ }^{\circ} \mathrm{C} / \mathrm{s}$ 이하의 느 린 냉각 속도에서 $0.5 \mathrm{Cu}-\mathrm{B}$ 시편의 변태 시작 온도는 오 스테나이트 변형에 의해 $0.5 \mathrm{Cu}$ 시편의 변태 시작 온도 보다 상대적으로 크게 높아진 반면, $20^{\circ} \mathrm{C} / \mathrm{s}$ 이상의 빠 른 냉각 속도에서는 오히려 그 반대 경향을 나타낸다(Fig. 1). 이는 오스테나이트 결정립계에서의 $\mathrm{B}$ 편석 거동으로 설명될 수 있다.

$\mathrm{B}$ 의 편석은 냉각 온도와 냉각 속도에 의존하는 편석
거동에 따라 크게 평형 편석(equilibrium segregation)과 비평형 편석(non-equilibrium segregation)로 나누어지며, 오스테나이트 결정립계에 편석되는 $\mathrm{B}$ 의 전체 양은 이들 의 합으로 이루어진다. 평형 편석에 의한 $\mathrm{B}$ 원자의 농 도는 다음의 식으로 주어진다. ${ }^{6,10)}$

$$
C_{e}=A C_{0} e^{Q / R T}
$$

여기서 $\mathrm{C}_{\mathrm{e}}$ 는 평형 상태에서 결정립계에 존재하는 원 자의 농도, $\mathrm{Q}$ 는 용질 원자와 결정립계의 결합에너지, $\mathrm{C}_{0}$ 는 기지의 용질 원자 농도, $\mathrm{A}$ 는 진동 엔트로피와 관련 된 상수이다. 따라서 온도가 높아질수록 결정립계 편석은 지수적으로 감소하며, 시편이 냉각될 때는 낮은 온도에 해 당되는 새로운 평형 상태에 도달하여 결정립계에 편석되 는 양이 증가한다. 반면 비평형 편석은 냉각 시 과잉으 로 형성된 공공이 결정립계로 이동하는 메커니즘에 의 해 $\mathrm{B}$ 원자들이 결정립계로 움직이기 때문에, 결정립계 에 편석되는 $\mathrm{B}$ 농도는 냉각 동안 결정립계로 소멸되는 
공공-용질 복합체(vacancy-solute complexes)의 수에 의해 결정된다. ${ }^{10)}$ 따라서 $\mathrm{B}$ 이 첨가된 강을 오스테나이트 영역 의 고온에서 냉각 시 평형 편석보다는 비평형 편석이 오 스테나이트 결정립계에 존재하는 $\mathrm{B}$ 의 전체 편석에 더 큰 영향을 준다. 비평형 편석의 경우 냉각되는 구간의 온 도 차이가 크고, 냉각 속도가 느릴수록 편석되는 $\mathrm{B}$ 의 농 도는 증가한다. $\mathrm{He}$ 등 $^{11)}$ 의 연구 결과에 따르면, $\mathrm{B}$ 이 첨 가된 강에 변형이 가해지면 동적 회복에 의해 오스테나 이트 결정립 내부에 아결정립들이 형성되며, 냉각 이전 오스테나이트에서의 변형은 공공 농도를 증가시켜 보다 많은 공공-B 복합체를 형성시키는 것으로 보고하였다. 이 로 인해 $0.5 \mathrm{Cu}-\mathrm{B}$ 시편은 연속 냉각 시 비평형 편석이 증대되기 때문에 $10{ }^{\circ} \mathrm{C} / \mathrm{s}$ 이하의 느린 냉각 속도에서는 오스테나이트 변형에 의한 변태 시작 온도의 상승이 $0.5 \mathrm{Cu}$ 시편보다 상대적으로 크다.

\section{2 미세조직과 기계적 특성}

본 연구에서 제조된 시편들의 광학현미경 미세조직 사 진을 Fig. 3에 나타내고, Table 1에 미세조직 분석 결과 를 정리하였다. $\mathrm{B}$ 이 첨가되지 않은 시편들은 $\mathrm{GB}$ 조직
이 많이 형성되어 있으며, $\mathrm{Cu}$ 함량이 높아짐에 따라 경 화능이 향상되어 $\mathrm{DUB}$ 나 $\mathrm{LB}, \mathrm{LM}$ 같은 저온 변태 조직 의 분율이 증가한다. $\mathrm{B}$ 이 첨가된 시편들의 미세조직은 대부분 $\mathrm{LB}, \mathrm{LM}$ 으로 구성되며, $\mathrm{Cu}$ 함량에 따라 조금씩 차이는 있지만 DUB가 $10 \sim 20 \%$ 정도 포함되어 있다.

$\mathrm{GB}, \mathrm{DUB}, \mathrm{LB}, \mathrm{LM}$ 을 모두 포함하고 있는 $1.5 \mathrm{Cu}$ 시 편의 미세조직을 $\mathrm{TEM}$ 으로 보다 자세히 관찰하여 Fig. 4에 나타내었다. $\mathrm{GB}$ 는 등축 형태의 베이나이트 결정립 사이에 단단한 마르텐사이트나 오스테나이트 또는 MA 상(martensite-austenite constituent)이 분산되어 있는 조직 으로 하부 구조가 잘 발달되어 있다. ${ }^{1,89} \mathrm{~GB}$ 에서 관찰되 는 베이나이트 결정립은 래스 형태의 베이나이트보다 높 은 온도에서 형성되는 변태 생성물로서 상대적으로 조대 한 결정립을 갖는다. $\mathrm{GB}$ 조직에서 탄화물은 거의 관찰 되지 않지만, 내부의 전위 밀도가 비교적 높고 하부 구 조가 잘 발달되어 있어 경도가 $250 \mathrm{Hv}$ 정도에 이른다.

DUB는 일반적인 UB(conventional upper bainite)와 같이 베이나이트가 침상형 또는 래스 형태로 되어 있는 점을 제외하고는 매우 다른 미세조직이다. 일반적인 UB 는 래스 경계에 판상의 시멘타이트가 연속적으로 존재
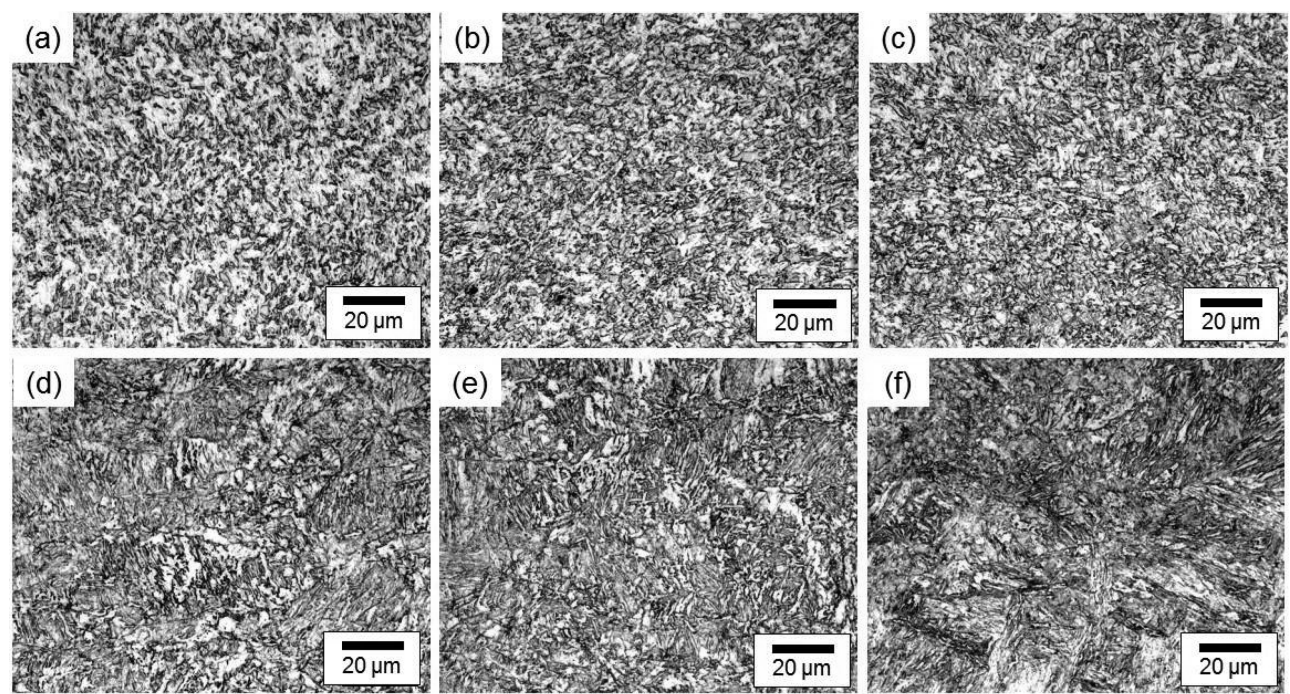

Fig. 3. Optical micrographs of the (a) $0 \mathrm{Cu}$, (b) $0.5 \mathrm{Cu}$, (c) $1.5 \mathrm{Cu}$, (d) $0 \mathrm{Cu}-\mathrm{B}$, (e) $0.5 \mathrm{Cu}-\mathrm{B}$, and (f) $1.5 \mathrm{Cu}-\mathrm{B}$ steel specimens. Nital etched.

Table 1. Microstructure and volume fractions of the high-strength low-alloy steel specimens investigated in this study.

\begin{tabular}{|c|c|c|c|c|c|c|}
\hline \multirow{2}{*}{ Specimen } & \multicolumn{2}{|c|}{ Microstructure } & \multicolumn{3}{|c|}{ Volume fraction $(\%)$} & \multirow{2}{*}{$\begin{array}{c}\text { Vickers hardness } \\
(\mathrm{Hv})\end{array}$} \\
\hline & Major phases & Minor phases & GB & DUB & $\mathrm{LB} / \mathrm{LM}$ & \\
\hline $0 \mathrm{Cu}$ & GB & - & 93 & 7 & - & 274 \\
\hline $0.5 \mathrm{Cu}$ & GB & DUB, LB/LM & 73 & 19 & 8 & 288 \\
\hline $1.5 \mathrm{Cu}$ & GB & DUB, LB/LM & 55 & 28 & 17 & 293 \\
\hline $0 \mathrm{Cu}-\mathrm{B}$ & $\mathrm{LB} / \mathrm{LM}$ & DUB & - & 19 & 81 & 369 \\
\hline $0.5 \mathrm{Cu}-\mathrm{B}$ & $\mathrm{LB} / \mathrm{LM}$ & DUB & - & 18 & 82 & 378 \\
\hline $1.5 \mathrm{Cu}-\mathrm{B}$ & $\mathrm{LB} / \mathrm{LM}$ & DUB & - & 11 & 89 & 395 \\
\hline
\end{tabular}



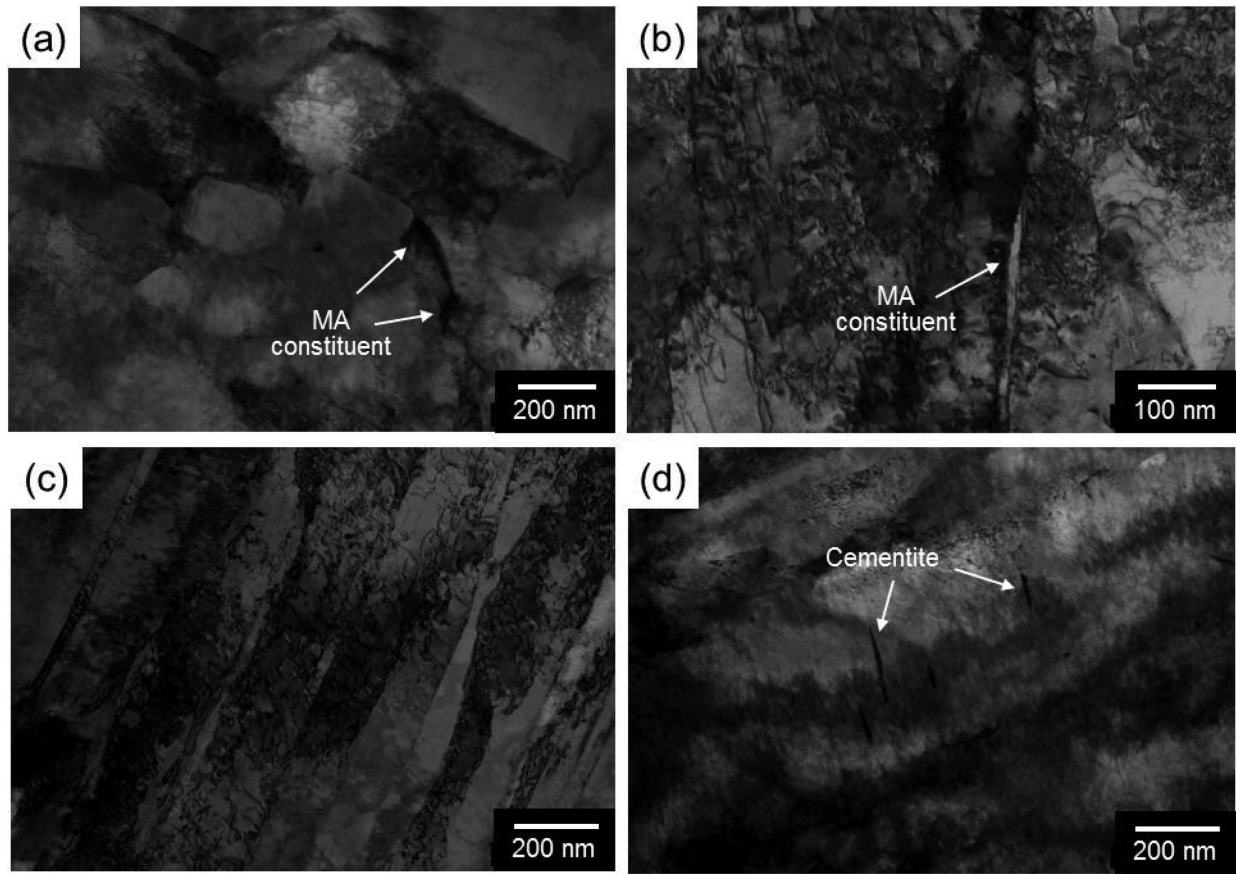

Fig. 4. TEM micrographs of the $1.5 \mathrm{Cu}$ steel specimen showing (a) GB(granular bainite), (b) DUB(degenerate upper bainite), (c) LB(lower bainite), and (d) LM(lath martensite) microstructure.
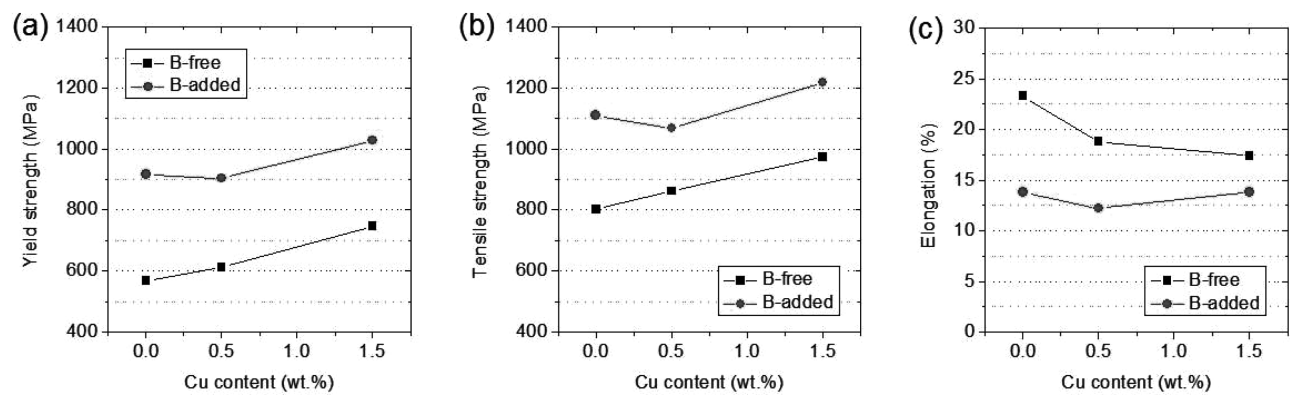

Fig. 5. (a) Yield strength, (b) tensile strength, and (c) elongation of the high-strength low-alloy steel specimens containing $\mathrm{B}$ and $\mathrm{Cu}$.

하고, 이들 취약한 시멘타이트들은 소성 유동을 방해하 여 인성에 나쁜 영향을 미친다.,5) 그러나 DUB의 경우 래스 사이에 탄소가 농축된 잔류 오스테나이트나 마르 텐사이트 또는 $\mathrm{MA}$ 조직과 같은 금속상들이 존재하여 기 존의 $\mathrm{UB}$ 보다 충분히 높은 인성을 가지고 있다. 그러나 너무 많은 양의 MA 입자는 인성에 나쁜 영향을 미치 는 것으로 보고되어 있다. ${ }^{1)}$

한편 $\mathrm{LB}$ 와 $\mathrm{LM}$ 은 매우 빠른 냉각 속도에서 주로 생 성되는 저온 변태 조직으로 같은 래스 형태의 구조를 갖 지만, 래스의 폭이나 전위 밀도, 2 차 상의 형태나 배열 등에 따라 구분될 수 있다. LB는 래스 형태의 베이나 이트 내에 고용된 탄소들이 미세하게 분산된 탄화물로 석출되고, 입방정 구조를 가지고 있어 다중 슬립계가 작 동하기 때문에 LM보다 상대적으로 높은 상부 흡수에너 지(upper shelf energy, USE)를 가진다. ${ }^{1,2)}$ 반면 LM은 많은 양의 탄소가 침입형 자리에 고용된 채 잔류되어 한
축으로 정방정 뒤틀림(tetragonal distortion)을 일으켜 슬 립계를 제한하기 때문에 격자 마찰과 탄소 고용으로 인 해 높은 강도를 갖지만, $\mathrm{LB}$ 에 비해 대체로 낮은 연성 과 인성을 갖는다. ${ }^{4,5)} \mathrm{LM}$ 은 일반적으로 탄화물이 존재 하지 않지만, 가속 냉각 후 공랭될 경우 오토 템퍼링 (auto-tempering)이 일어나 마르텐사이트 래스 내부에 탄 화물들이 다양한 방향으로 석출되기도 한다(Fig. 4(d)).

본 연구에서 제조된 시편들의 인장 및 충격 특성을 Fig. 5 와 Fig. 6 에 각각 나타내었다. $\mathrm{B}$ 이 첨가된(B-added) 시 편들은 $\mathrm{B}$ 이 첨가되지 않은(B-free) 시편들에 비해 항복 강도와 인장 강도가 모두 높으며, $\mathrm{Cu}$ 함량이 높아짐에 따라 강도는 대체로 증가하고, 연신율은 감소하였다. 이 는 $\mathrm{B}$ 이 첨가되지 않은 시편들의 경우 $\mathrm{GB}$ 조직을 많이 포함하고 $\mathrm{Cu}$ 함량 증가에 따라 $\mathrm{DUB}$ 나 $\mathrm{LB} / \mathrm{LM}$ 가 형성 되며, $\mathrm{B}$ 이 첨가된 시편들의 경우 $\mathrm{LB} / \mathrm{LM}$ 조직이 대부 분으로 형성되고 $\mathrm{Cu}$ 함량 증가에 따라 그 분율이 높아 

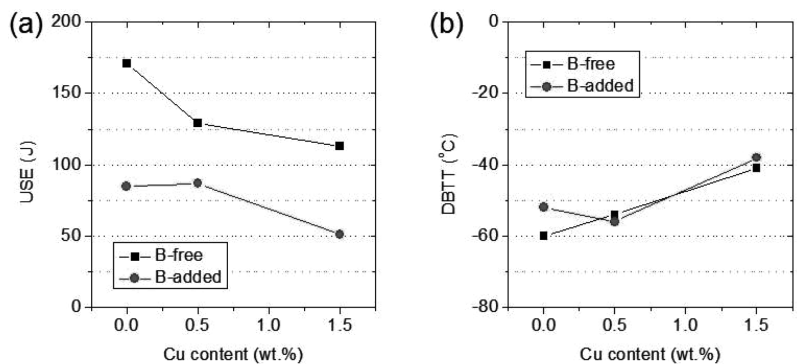

Fig. 6. (a) USE(upper-shelf energy) and (b) DBTT(ductile-brittle transition temperature) of the high-strength low-alloy steel specimens containing $\mathrm{B}$ and $\mathrm{Cu}$.

지기 때문이다. 특히 $\mathrm{Cu}$ 함량이 $0.5 \mathrm{wt} . \%$ 에서 $1.5 \mathrm{wt.} \%$ 로 높아질 때 연신율의 저하없이 항복 강도와 인장 강 도가 $100 \mathrm{MPa}$ 이상 크게 증가한다. 이는 $1.5 \mathrm{wt} . \%$ 의 $\mathrm{Cu}$ 첨가에 의한 뚜렷한 고용강화 효과 이외에 가속 냉각으 로 변태되는 도중에 형성된 매우 미세한 석출물의 영향 으로 생각된다. ${ }^{4,7,12)}$

한편 $\mathrm{B}$ 과 $\mathrm{Cu}$ 첨가에 따른 시편들의 충격 특성을 살 펴 보면, $\mathrm{B}$ 이 첨가된 시편들은 $\mathrm{B}$ 이 첨가되지 않은 시 편들에 비해 상부 흡수에너지(USE)는 낮지만, 연성-취성 천이 온도(DBTT)는 거의 같은 것으로 나타났다. 이는 고 강도 저합금강에서 $\mathrm{B}$ 의 첨가가 상부 흡수에너지를 다소 감소시키지만, 강도와 저온인성을 모두 향상시키는데 효 과적임을 의미한다. 또한 $\mathrm{Cu}$ 함량 증가에 따라 상부 흡 수에너지는 서서히 감소하며, 연성-취성 천이 온도는 $10 \sim 20{ }^{\circ} \mathrm{C}$ 정도 증가되었다. 이는 $\mathrm{Cu}$ 함량 증가에 낮은 인 성을 갖는 $\mathrm{DUB}$ 나 $\mathrm{LB} / \mathrm{LM}$ 분율이 증가하기 때문이다.

\section{4. 걸}

$\mathrm{B}$ 과 $\mathrm{Cu}$ 를 함유한 고강도 저합금강은 연속냉각 변태 과 정 동안 화학조성, 변형, 냉각 속도에 따른 상변태에 의 해 변태 온도가 낮아짐에 따라 $\mathrm{QPF}, \mathrm{GB}, \mathrm{DUB}, \mathrm{LB}$, $\mathrm{LM}$ 의 순서로 다양한 저온 변태 조직이 형성되었다. 미 량의 $\mathrm{B}$ 첨가는 경화능을 크게 향상시켜 변태 온도를 낮 추고, 저온 변태 조직이 형성되는 영역을 느린 냉각속 도 범위로 이동시켰다. 오스테나이트에서의 변형은 변태 시작 온도를 크게 높이지만, 변태 종료 온도에는 큰 영 향을 주지 않았다. $\mathrm{B}$ 이 첨가된 시편에 대한 오스테나이
트에서의 변형은 비평형 편석에 의해 오스테나이트 입 계에 편석되는 $\mathrm{B}$ 농도를 증가시킴으로써 경화능을 크게 향상시켰다. 한편 $\mathrm{B}$ 이 첨가된 시편들은 $\mathrm{B}$ 이 첨가되지 않 은 시편들에 비해 항복 강도와 인장 강도가 모두 높으 며, 연신율과 상부 흡수에너지는 다소 낮지만, 연성-취성 천이 온도가 거의 같은 우수한 저온인성을 나타내었다. B 첨가에 관계없이 $\mathrm{Cu}$ 함량 증가에 따라 강도는 높아지 지만, 인신율과 상부 흡수에너지는 서서히 감소하였다. $\mathrm{Cu}$ 함량이 $0.5 \mathrm{wt} . \%$ 에서 $1.5 \mathrm{wt} . \%$ 로 증가될 때 항복 강도와 인장 강도는 연성의 큰 저하없이 $100 \mathrm{MPa}$ 이상 크게 증 가하였다. 이는 $\mathrm{Cu}$ 첨가에 의한 뚜렷한 고용강화 효과 이외에 가속 냉각으로 변태되는 도중에 형성된 매우 미 세한 석출물의 영향으로 생각되었다.

\section{References}

1. J. Koo, M. J. Luton, N. V. Bangaru, R. A. Petkovic, D. P. Fairchild, C. W. Petersen, H. Asahi, T. Hara, Y. Terada, M. Sugiyama, H. Tamehiro, Y. Komizo, S. Okaguchi, M. Hamada, A. Yamamoto, I. Takeuchi, Int. J. Offshore and Polar Eng., 14, 2 (2004).

2. B. Hwang, C. G. Lee, S. Lee, C. Lee, Trends in Metals \& Materials Engineering, The Korean Institute of Metals and Materials, 22, 28 (2009).

3. D. Raabe, D. Ponge, O. Dmitrieva, B. Sander, Adv. Eng. Mater., 11, 547 (2009).

4. I. Tamura, H. Sekine, T. Tanaka, C. Ouchi: Thermomechanical Processing of High-Strength Low-Alloy Steels, Butterworth \& Co. Ltd., London, 1988.

5. T. Gladman: The Physical Metallurgy of Microalloyed Steels, The Institute of Materials, London, 1997.

6. D. H. Werner, Boron and Boron Containing Steels, Verlag Stahleisen mbH, Düsseldorf (1995).

7. A. Ghosh, B. Mishra, S. Das, S. Chatterjee, Mater. Sci. Eng., A, 374, 43 (2004).

8. B. L. Bramfitt and J. G. Speer, Metall. Mater. Trans. A, 21, 817 (1990).

9. G. Krauss and S. W. Thompson, ISIJ Int., 35, 937 (1995).

10. L. Karlsson, H. Norden and H. Odelius, Acta Metall., 36, 1 (1988).

11. X. L. He, Y. Y. Chu and J. J. Jonas, Acta Metall., 37, 147 (1989).

12. S. K. Ghosh, A. Haldar, P. P. Chattopadhyay, Mater. Sci. Eng., A, 519, 88 (2009). 